\title{
PROLIFERATIVE MYOSITIS - A CASE REPORT WITH REVIEW OF LITERATURE
}

Mamina Bhoi ${ }^{1}$, Sarvesh B.M², Prem Charles D³, P. Viswanathan ${ }^{4}$, Rehana Tippoo ${ }^{5}$

\section{HOW TO CITE THIS ARTICLE:}

Mamina Bhoi, Sarvesh B.M, Prem Charles D, P. Viswanathan, Rehana Tippoo. "Proliferative Myositis - A Case Report with Review of Literature". Journal of Evolution of Medical and Dental Sciences 2014; Vol. 3, Issue 03, January 20; Page: 673-677, DOI: 10.14260/jemds/2014/1884

ABSTRACT: Proliferative myositis is the intramuscular counterpart of proliferative fasciitis. It is a rapidly growing, benign lesion that infiltrates muscle tissue in a diffuse manner and is characterised by bizarre giant cells bearing a close resemblance to ganglion cells. Rarely occurs in young adults. A thirty year young female presented with complaints of a solitary swelling in the right infra-scapular region since one year. The swelling was clinically diagnosed as, Right infra-scapular fibroma. Excision was done under local anaesthesia and was sent for histopathological examination. Histopathological diagnosis was confirmed as Proliferative myositis.

KEYWORDS: Solitary swelling, Infra-scapular, Proliferative Myositis

INTRODUCTION: Proliferative myositis is a rapidly growing, reactive lesion and is an intramuscular counterpart of proliferative fasciitis. Although, Kern is credited with the original description of proliferative myositis ${ }^{1}$, Ackerman reported the first cases in his study ${ }^{2}$. The patients tend to be older, with a median age of 50 years $^{3}$. It is rare in children and young adults with no gender or race predilection ${ }^{4}$. Approximately a thousand cases have been reported in literature ${ }^{5}$. It mainly affects the flat muscles of the trunk and shoulder girdle, especially the pectoralis, latissimus dorsi or serratus anterior muscle. Occasionally, tumours are also found in the muscles of the thigh. In this case, the age incidence and duration of the lesion was a rare presentation.

CASE HISTORY: An otherwise well doing thirty year female presented with a solitary swelling in the right infra-scapular region since one year. The swelling was not associated with pain. No history of any other swelling in the body. Family history was nil relevant. On clinical examination a single spherical swelling measuring $2 \times 1 \mathrm{~cm}$ was present in the right infra-scapular region. Surface was smooth and the plane of the swelling was deep to muscle. Skin over the swelling was normal and no dilated veins or punctum were noted. The swelling was firm in consistency, mobile, not warm, not tender. Excision was done as a day care procedure. Under local anaesthesia, a curvilinear incision was done. An intramuscular swelling was identified measuring $2 \times 1 \mathrm{~cm}$. Swelling was excised in Toto. Dead space was obliterated and skin was sutured. The excised tumour was sent for histopathological examination.

MACROSCOPY: Container had a grey black partially skin covered soft tissue piece measuring $2 \times 1 \times 0.5$ $\mathrm{cm}$. Cut section revealed solid, grey white areas.

MICROSCOPY: Multiple sections studied on Hematoxylin and Eosin stain revealed elongated spindle shaped cells with tapering ends and wavy nucleus distributed in sweeping interlacing bundles and have infiltrated the skeletal muscle tissue and adjacent adipocytes [Figure1, 2 \& 4]. There were 
extravasated erythrocytes among fascicles [Figure 3, 6 \& 7]. Pseudo ganglion like cells were present [Figure 5]. Muscle tissue showed atrophy. Areas of hyalinisation and myxoid degeneration were present [Figure $8 \&$ 9]. Features were consistent with the diagnosis of Proliferative myositis.

DISCUSSION: Proliferative myositis presents as a palpable, discrete, solitary nodular mass that measures 1-6 cm in diameter. Rarely causes tenderness or pain. The duration between onset and excision is usually less than 3 weeks ${ }^{3,6}$.

It is a self-limiting, benign, reactive lesion in which there is a poorly demarcated proliferation of fibroblast-like cells that involve the epimysium, perimysium and endomysium. This cellular proliferation is most striking in the subfascial region and interfascicular connective tissue septa. The skeletal muscle fibers are relatively unaffected except for the presence of secondary atrophy. Hallmark of this lesion is the presence of very large basophilic cells with vesicular nuclei and very prominent nucleoli, resembling ganglion cells or rhabdomyoblasts. These cells proliferate between the muscle fibers and then separate each of them so that, at low power, a distinctive "checkerboard" appearance is visible. Occasional giant cells contain eosinophilic collagen inclusions. Mitotic figures are often easily identified in both the spindle and giant cells, although atypical mitoses are never seen.

Immunohistochemical and ultra-structural features of proliferative myositis are identical to proliferative fasciitis, with most cells showing evidence of myofibroblastic differentiation 5 . Both the spindle and giant cells express vimentin, muscle-specific actin and smooth muscle actin. Immunostains for desmin and myoglobin are typically negative ${ }^{7}$. Trisomy 2 has been described ${ }^{8}$ and $t$ $(6 ; 14)$ was described in a single case 9.

It is probably preceded by some type of fascial or muscular injury resulting in a proliferation of myofibroblasts. However, only a small number of patients report a preceding injury in the exact location of the lesion, raising the possibility that causes other than mechanical trauma play a role in the development of proliferative myositis. The lesions are adequately treated by local excision, and recurrence is rare ${ }^{10}$

\section{Differential Diagnosis:}

1. Rhabdomyosarcoma- History of a rapidly growing mass of short duration that typically attains a maximum size of less than $3 \mathrm{~cm}$ is more consistent with a reactive process. The ganglion-like cells lack cross-striations.

2. Ganglioneuroblastoma- Proliferative myositis lacks a fibrillary background and the ganglion-like cells may express actin, unlike true ganglion cells.

\section{REFERENCES:}

1. Kern WH. Proliferative myositis; a pseudosarcomatous reaction to injury: a report of seven cases. Arch Pathol 69:209, 1960.

2. Ackerman LV. Extra-osseous localized non-neoplastic bone and cartilage formation (so-called myositis ossificans): clinical and pathological confusion with malignant neoplasms. J Bone Joint Surg (Am) 40:279, 1958.

3. Enzinger FM, Dulcey F. Proliferative myositis: report of thirty-three cases. Cancer 20:2213, 1967.

4. Meis JM, Enzinger FM. Proliferative myositis of childhood. Am J Surg Pathol 16:364, 1992. 
5. Jassar A, Kumar V. Proliferative Myositis - A Case Report. Indian Journal of Pathology and amp; amp; amp; Microbiology; an official origin of Indian Association of Pathologist \& Microbiologist 28(3): 273-276, 1985.

6. Gokel JM, Meister P, Hubner G. Proliferative myositis: a case report with fine structural analysis. Virchows Arch (Pathol Anat Histol) 367:345, 1975.

7. El-Jabbour JN, Bennett MH, Burke MM, et al. Proliferative myositis: an immunohistochemical and ultrastructural study. Am J Surg Pathol 15:654, 1991.

8. Ohjimi Y, Iwasaki H, Ishiguro M, et al. Trisomy 2 found in proliferative myositis cultured cell. Cancer Genet Cytogenet 76:157, 1994.

9. McComb EN, Neff JR, Johansson SL, et al. Chromosomal anomalies in a case of proliferative myositis. Cancer Genet Cytogenet 98:142, 1997.

10. Chung EB, Enzinger FM. Proliferative fasciitis. Cancer 36:1450, 1975.

\section{FIGURES:}

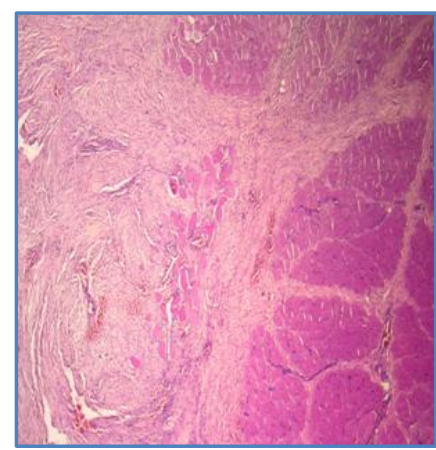

Fig. 1: (4X)

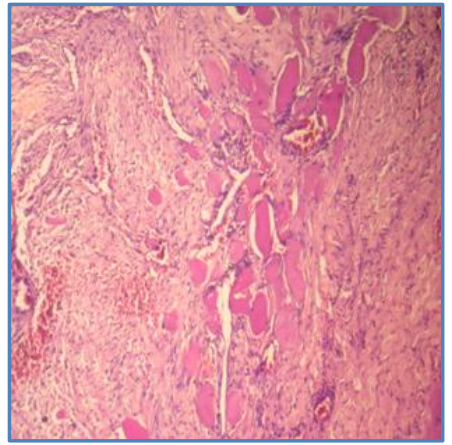

Fig. 2: (10X)

Fig. 1 \& 2: The muscle bundles are separated by endomycial and epimycial proliferation of fibrous connective tissue in a checkerboard-like fashion- in low power view and high power.

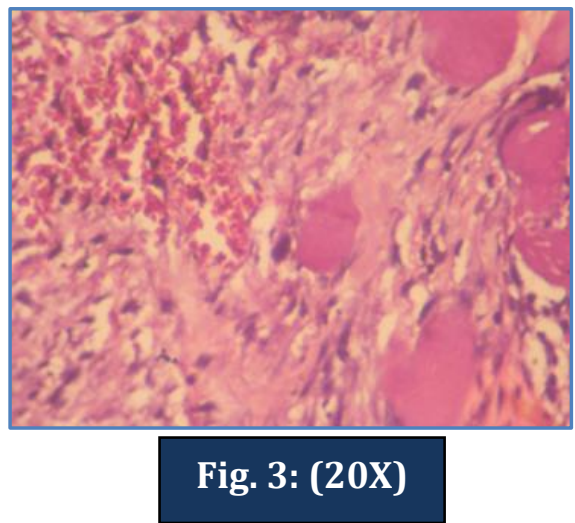

Fig. 3: Shows extravasated erythrocytes interspersed among the sweeping interlacing fascicles and ganglion like cells. 


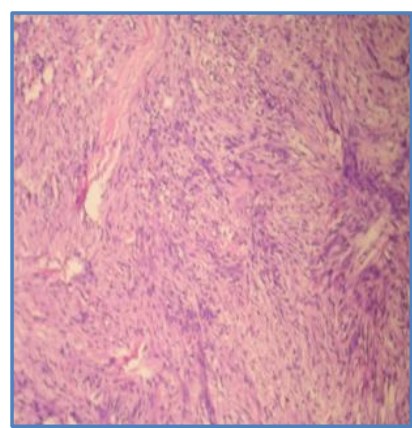

Fig. 4: (4X)

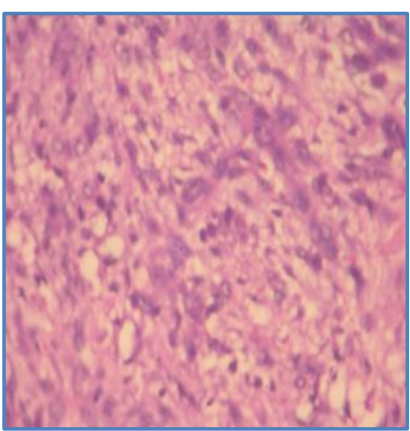

Fig. 5: (10X)

Fig. 4: Shows elongated spindle shaped cells with tapering ends and wavy nucleus distributed in sweeping interlacing bundles.

Fig. 5: Shows the ganglion like cells along with the spindle shaped cells.

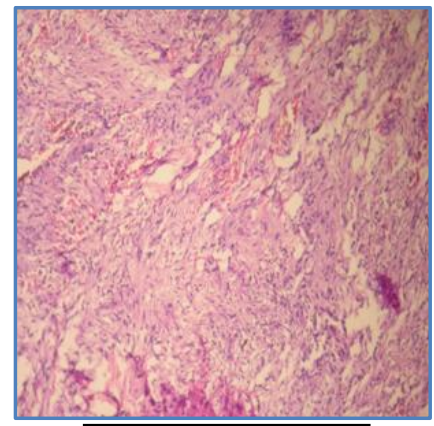

Fig. 6: (4X)

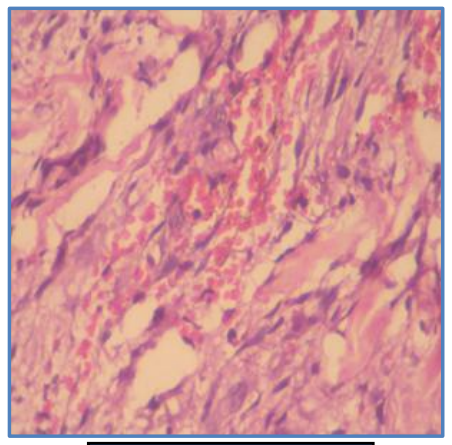

Fig. 7: (10X)

Figure $6 \&$ 7: There were extravasated erythrocytes among the sweeping interlacing fascicles of spindle shaped cells.

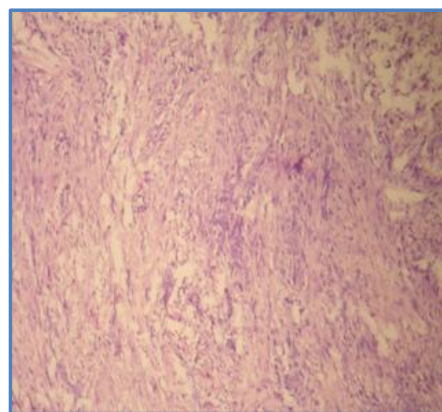

Fig. 8: (4X)

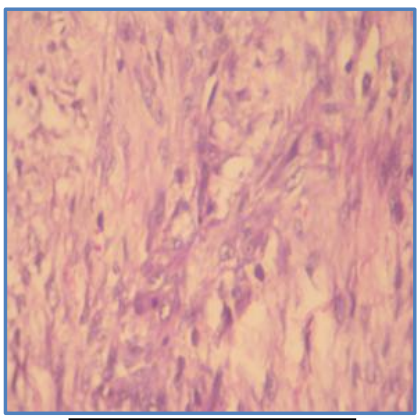

Fig. 9: (10X)

Fig. 8 \& 9: Shows areas of hyalinisation and myxoid degeneration.

- $\quad$ All the microscopic pictures were taken using Nikon Cool pix Model 8400.

- X-Indicates the power of Objective.

- Stain used - Haematoxylin and Eosin. 


\section{AUTHORS:}

1. Mamina Bhoi

2. Sarvesh B.M.

3. Prem Charles D.

4. P. Viswanathan

5. Rehana Tippoo

\section{PARTICULARS OF CONTRIBUTORS:}

1. IIIrd Year Post Graduate, Department of Pathology, Rajah Muthiah Medical College, Annamalai University.

2. IIIrd Year Post Graduate, Department of Pathology, Rajah Muthiah Medical College, Annamalai University.

3. Iind Year Post Graduate, Department of Pathology, Rajah Muthiah Medical College, Annamalai University.

4. Professor, Department of Pathology, Rajah Muthiah Medical College, Annamalai University.
5. Professor, Department of Surgery, Rajah Muthiah Medical College, Annamalai University.

\section{NAME ADDRESS EMAIL ID OF THE CORRESPONDING AUTHOR:}

Dr. P. Viswanathan,

Professor,

Department of Pathology, Faculty of Medicine, Rajah Muthiah Medical College,

Annamalai University, Chidambaram,

Tamilnadu, India, PIN - 608002.

E-mail: drpviswanathan1@gmail.com

Date of Submission: 29/11/2013.

Date of Peer Review: 30/11/2013.

Date of Acceptance: 04/01/2014.

Date of Publishing: 16/01/2014. 